\title{
Ortalama Evlilik Yaşının Yükselmesini Etkileyen Faktörler ve Cinsiyete Göre Farklılıklar
}

\author{
Anıl ERALP*, Şahika GÖKMEN**
}

öz

Son yıllarda sosyal hayatta yaşanan dönüşüm ve bireyselleşme ile Türkiye'de ortalama ilk evlilik yaşının yükseldiği görülmektedir. Bireylerin evliliği ertelemesi, toplumun temel yapıtaşı olan aile kurumunun devamının sağlanması işlevini sarsmaktadır. Bu çalışmada Türkiye'de evliliği erteleme ya da geç evlenme sorunu olarak adlandırılan bireylerin evlenme yaşını öteleyen faktörlerin etkisi ve cinsiyet bakımından farklılığı, yaşam analizi ile incelenmiştir. Bu çerçevede TÜİK AYA 2016 verileri içerisinde yer alan temel sosyo-ekonomik ve evlilik karar ölçeklerinden yararlanılmış olup, ortalama evlilik yaşının yükselmesinde etkisi olan faktörler Cox regresyon modeli üzerinden araştırılmıştır. Çalışmada elde edilen bulgular literatürdeki diğer çalışmalarla uyumlu olup, özellikle kadınların bireyselleşmeye daha eğilimli olduğu ve dolayısıyla bunun evliliği erteleme üzerinde olumsuz etkileri olduğunu işaret ettiği söylenebilir. Buna karşlık erkeklerin tutumlu ve az çalışma saati olan eş ile ve kadınların ise cömert ve kendini eşin ailesine ezdirmeyen eş adayı ile karşılaşmış olmaları bireylerin evliliği erteleme riskini düşürdüğü görülmüştür. Bu aynı zamanda, Türkiye'deki geleneksel aile yapısının korunduğunun bir göstergesi olarak yorumlanabilir.

\section{Anahtar Kelimeler: Yaşam Analizi, Cox Regresyon, Oransal Risk, Geç Evlenme, Evlenme Yaş1}

JEL Sinıflandırması: J12, C14, C25

\section{The Factors Affecting the Late Marriage and Gender Differences}

\begin{abstract}
In recent years, faced with cultural transformations and individualization of social life, it is seen that the average age at first marriage increased in Turkey. The postponing of the marriage is the main function of the family institution, which the basic building block of the society. This study is aimed to research the factors on the problem of the postpone marriage or the late marriage in terms of gender differences in Turkey via survival analysis. In this framework, the basic socio-economic and marriage decision variables included in Cox regression model while TÜIKK AYA 2016 data were used. The findings obtained in the study are compatible with other studies in the literature. Also, it can be said that especially women are more prone to individualization and this has negative effects on the postponing of the marriage. Conversely, it was observed that when men find a spouse who is spare and fewer working hours; and when women find a spouse who is generous and is not oppress by her husband's family, are reduced the risk of marital delay. These findings can be taken as an indication that the protection of the traditional family structure in Turkey.
\end{abstract}

Keywords: Survival Analysis, Cox Regression, Proportional Hazards, Late Marriage, Marriage Age

JEL Classification: J12, C14, C25

Geliş Tarihi / Received: 03.03.2020 Kabul Tarihi / Accepted: 07.04.2020

\footnotetext{
* Dr. Öğr. Üyesi, Bolu Abant İzzet Baysal Üniversitesi, İİBF, Ekonometri Bölümü, anil.eralp@ibu.edu.tr, ORCID: 0000-0002-4630-2114.

** Araş. Gör. Dr., Ankara Hacı Bayram Veli Üniversitesi, İ̈BF, Ekonometri Bölümü, sahika.gökmen@hbv.edu.tr, ORCID: 0000-0002-4127-7108.
} 


\section{GİRIŞ}

Aile toplumsal bir kurum olarak, toplumsal yapının ve sosyal sistemin sağlıklı bir şekilde işlemesi ve sürekliliğinin devam etmesi açısından önemlidir (Erkal, 2016: 117-118; Aydın, 2017: 45). Teknolojideki hızlı ilerlemeler ve ekonomik hayattaki değişim, batı toplumlarından başlayarak dünya genelinde bireylerin ve dolayısıyla toplumların yaşam tarzlarını etkileyerek; kültürel değişimleri beraberinde getirmiştir. Özellikle kadınların çalışma hayatındaki payının artması, toplumsal ve dini öğretilerin bireyler üzerindeki etkisinin azalması ve küreselleşme gibi etkiler; toplumlarda bireyselleşmeyi arttırmış ve geleneksel aile yapısında aşınmaya neden olmaya başlamıştır. Ancak, toplumsal hayatın sağlıklı bir şekilde sürdürülebilmesi, aile kurumunun varlığının devamlılığına ve sağlıklı bir şekilde işlemesine bağlıdır. Aksi takdirde boşanma oranlarındaki hızlı artış, tek ebeveynli aile sayısındaki artış, evliliğe karşı çıkış ve/veya evliliği erteleme, nikahsız birlikteliklerin sayısındaki artış, çocuk yapmama eğilimindeki artş̧, aile-içi şiddet gibi çeşitli toplumsal sorunlar ortaya çıkabilmektedir (Bkz. ASPB, 2011: 31-34).

Dünya üzerindeki pek çok ülke ortalama evlilik yaşının yükselmesiyle birlikte ortaya çıkan sorunlarla ilgilenmektedir. Şekil 1, bunun bir göstergesi olarak ele alınabilir. Burada en çok dikkat çeken nokta, hemen hemen her ülkenin ilk evlilik yaşının 1990 yılına göre artış gösterdiğidir. Bununla birlikte, 1990 ve 2000 yıllarında ilk evlenme yaş1 yüksek olan ülkeler, 2017 y1l genel ortalamasına olan 31,23 ( $\pm 2,0$ ss)'e yaklaşırken; geçmiş yıllarda ilk evlenme yaşı daha düşük olan Litvanya, Çek Cumhuriyeti, Macaristan gibi ülkeler de 2017 yılı genel ortalamasına yaklaşmaktadır. Ancak, 1990 ve 2000 yıllarında daha düşük ortalama evlenme yaşına sahip olan bu ülkelerin evlenme yaşları yükseliş göstermiş̧ir. Aynı zamanda Türkiye, İsrail ve Meksika gibi ülkelerin 2017 yılı ortalamalarının dünya genelinin altında bulunduğu da gözlenmektedir. Buna karşılık Türkiye Nüfus ve Sağlık Araştırması (TNSA) 2008 sonuçlarına göre, Türkiye'de ilk evlenme yaşının hızlı bir şekilde yükseldiği ve takip eden yıllarda yükselmeye devam edeceği ileri sürülmektedir (Turğut \& Feyzioğlu, 2014: 191). Bu bakımdan ortalama ilk evlenme yaşının yükselmesi, özellikle son yıllarda Türkiye için bir sorun haline gelmeye başlamıştır. 


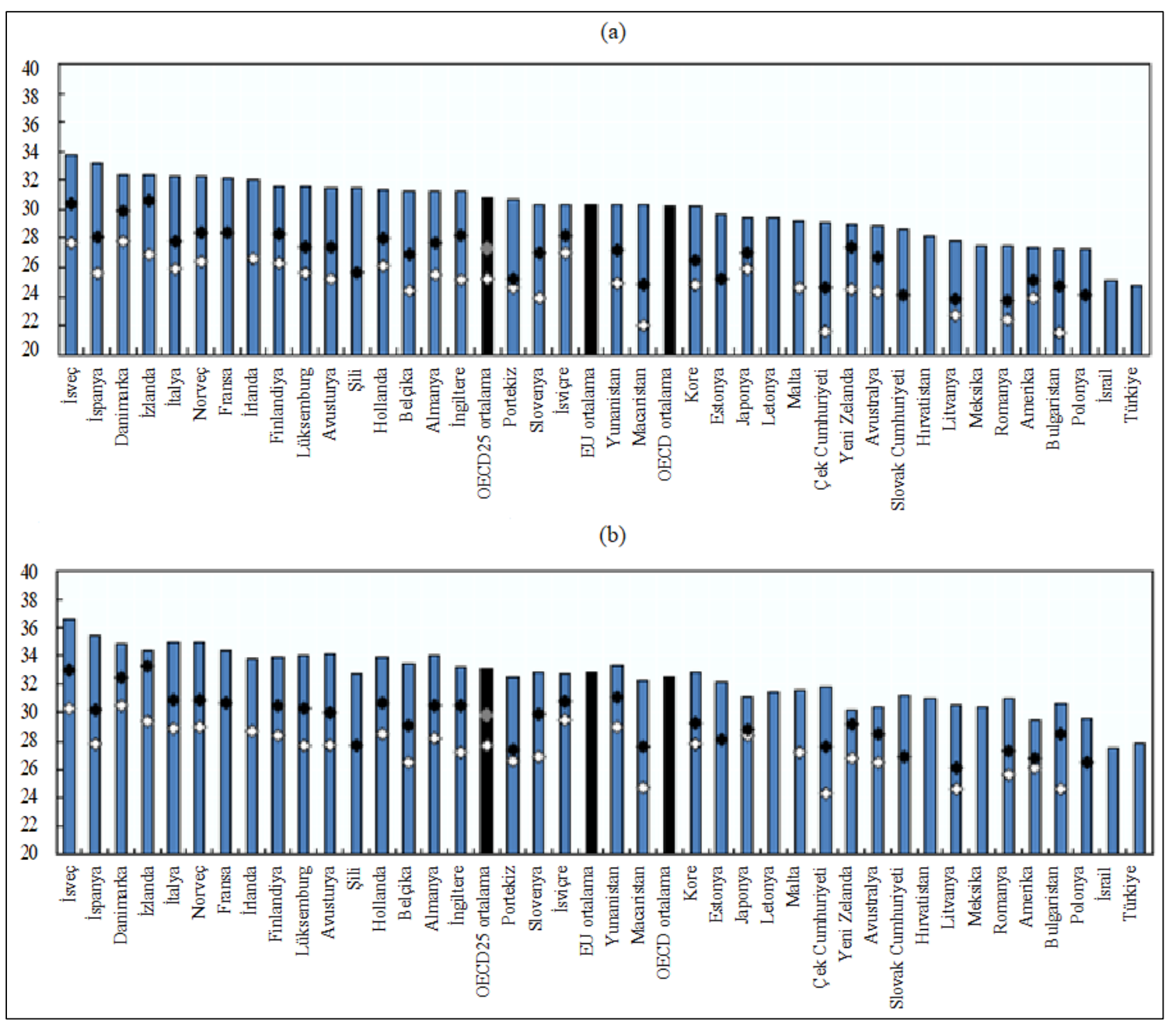

Şekil 1. Ülkelerin (a) Kadın ve (b) Erkek Ortalama Evlenme Yaşları. (Grafiğin düşey ekseni "ortalama yaşı" temsil etmekle birlikte, mavi çubuklar 2017 yılına ait verilerden oluşturulmuş olup; siyah noktalar 2000 ve beyaz noktalar ise 1990 yılının yaş ortalamalarını temsil etmektedir.)

Kaynak: OECD Summary Data Base (Güncelleme: 30.06.2019).

2001-2018 dönemi için Türkiye İstatistik Kurumu'ndan (TÜIK) elde edilen, "cinsiyete ve yaş gruplarına göre ilk evlenme sayıları" incelenerek Şekil 2 oluşturulmuştur. Bu şekil, evliliğin ileriki yaş dönemlerine ertelendiğinin bir göstergesi olarak değerlendirilebilir. Şekil 2 'de söz konusu dönem için erkeklerin evlenme oranlarında 20-24 yaş aralığında yüksek bir azalış eğiliminde olduğu ve bu oranın 25-29 yaş aralığında en yüksek seviyeye ulaştığı görülmektedir. Kadınlar için, en yüksek evlenme oranı 20-24 yaş aralığında gözlenirken bu oranda y1llara göre bir düşüş dikkati çekmektedir. Bununla beraber hem erkeklerde hem de kadınlarda 30 ve üstü yaşlarda evlenme oranın artış gösterdiği görülmektedir. 


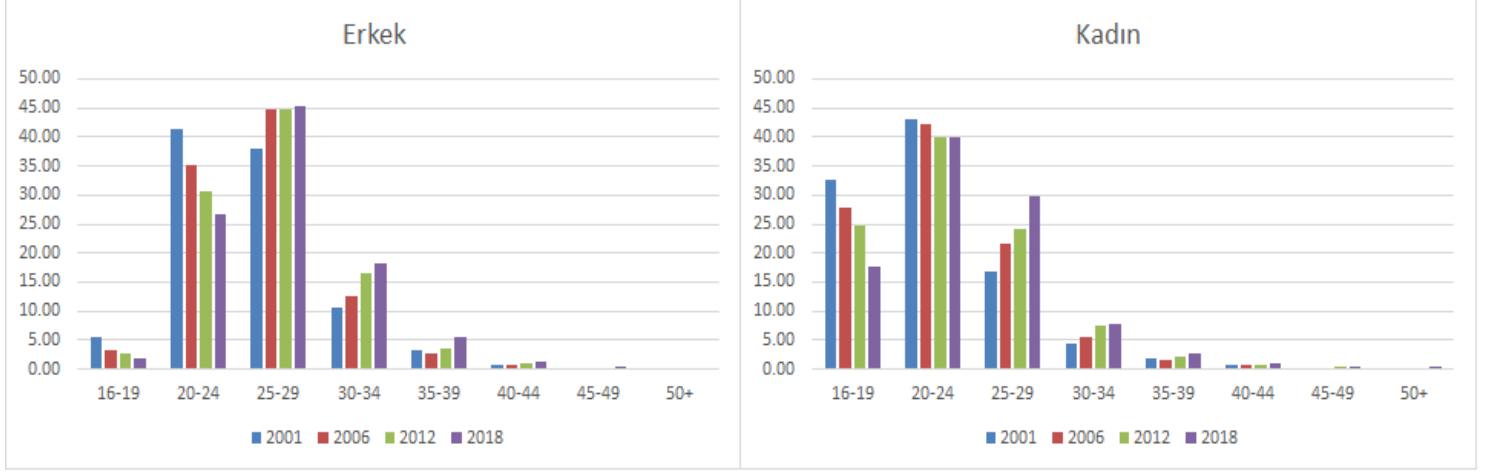

Şekil 2. 2001 - 2018 Yılları Arası Cinsiyete ve Yaş Gruplarına Göre Evlenme Oranları.

Dünya genelinde, genellikle, evlilik bağının kurulması doğurganlık için bir ön koşul olarak kabul edilmektedir (Tezcan \& Coşkun, 2004). Dolayısıyla, evliliğin ertelenmesi, aile kurumunun temel işlevlerinden biri olan soyun devamlılığını olumsuz yönde etkileyerek (Canatan \& Yıldırım, 2018: 85), doğurganlık oranlarında düşüşe neden olmaktadır. Ortalama ilk evlenme yaşının yükseldiği bir ülke olarak Türkiye için Şekil 3 incelendiğinde, 25 yaş altında 2001 y1lından 2018 yılına kadar süreklilik gösteren bir doğurganlık düşüşü olduğu; buna karş1lık 25-29 yaş grubu için bu süreçte doğurganlığın diğer yaş gruplarına göre en yüksek seviyede olduğu görülmektedir. Bununla ilişkili olarak TNSA 2008 sonuçlarına göre, doğurganlık seviyesinin önümüzdeki 40 yılda Batı Avrupa'da gözlenmesi beklenen doğurganlık seviyesinin altına düşme ihtimali bulunmaktadır. Dolayısıyla hem ülkenin nüfusunda yaşlanma ve hem de ülkenin dinamik nüfus özelliğinin kaybolması sorunları ortaya çıkabilir.

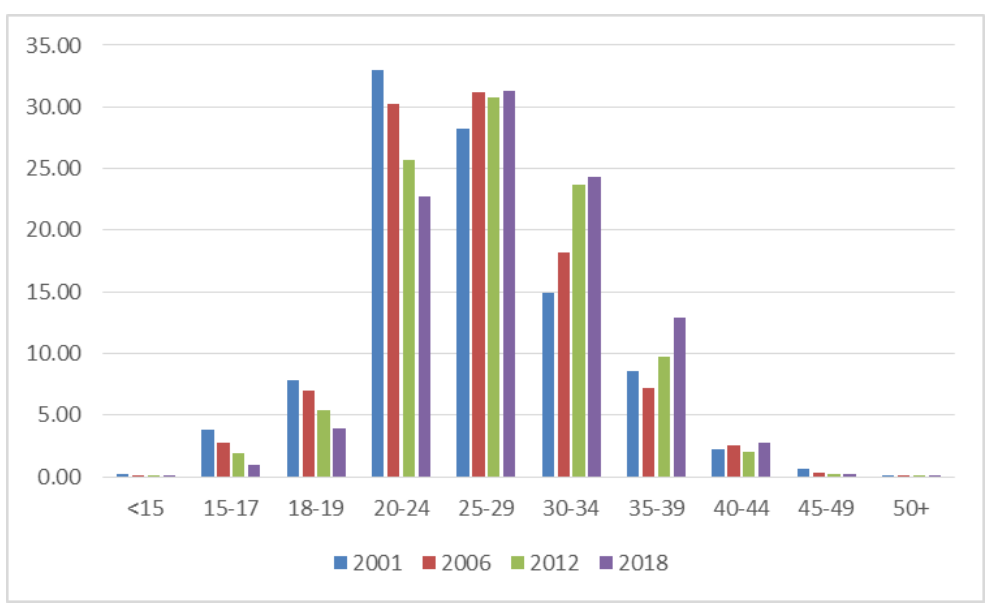

Şekil 3. 2001-2008 Yılları Arası Yaş Gruplarına Göre Doğurganlık Oranları.

Ortalama evlilik yaşının yükselmesi ve beraberinde gelen doğurganlığın düşmesi, yalnızca aile veya toplumun demografik yapısını değil, aynı zamanda ülkenin ekonomisini de etkilemektedir. Türkiye özelinden bakıldığında, Dünya Bankası'nın 2019 gelir temelli sinıflamasına göre üst-orta gelir grubunda yer alan Türkiye'nin nüfus dinamizmini kaybetmesi, Türkiye'nin üst gelir grubuna çıkması bakımından önemli bir tehdit potansiyeli taşımaktadır.

Türkiye'de aile yapısı üzerine yapılan saha araştırmaları incelendiğinde ilk çalışma olarak karşımıza 1968 yılında Hacettepe Üniversitesi Nüfus Etütleri Enstitüsü tarafından gerçekleştirilen Türkiye'de Aile Yapısı ve Nüfus Sorunları Araştırması çıkmaktadır. İkinci çalışma ise, 1988 yılında Devlet Planlama Teşkilatı (DPT) tarafından yapılan Türk Aile Yapısı Araştırmasıdır. Diğer çalışma, 2006 yılında Aile Sosyal Araştırmalar Genel Müdürlüğü ve TÜİK'in birlikte gerçekleştirdikleri Aile Yapısı Araştırması'dır. Bu çalışmalar incelendiğinde, 
1968 yılındaki saha çalışmasından elde edilen verilerin büyük bir kısmının 1988 ve 2006 saha çalışmalarından elde edilen veriler ile karşılaştırılabilmeleri mümkün değildir. 1988 ve 2006 çalışmaları büyük ölçüde karşılaştırma yapılmasına izin vermekle birlikte, her iki çalışmanın araştırma tasarımındaki farklılıklar ile aile konusundaki teorik ve uygulamalı araştırma bilgi birikiminin artmış olması gibi sınırlıkları bulunduğu belirtilmektedir (ASPB, 2011: 27). Türkiye'de aile yapısındaki değişimleri takip edebilmek amacıyla Aile ve Toplum Hizmetleri Genel Müdürlüğü tarafından 2006 yılında Aile Yapısını Araştırma (AYA) çalışmaları başlatılmıştır. Bu bakımdan, 2006 yılında yapılan Aile Yapısı Araştırması, Türkiye'de aile yapısındaki değişimlerin izlenmesi ve bu konuda nicel veriler sağlaması bakımından bir milat olarak düşünülebilir.

Literatürde ortalama evlilik yaşının yükselmesi ile ilgili çalışmalar 1980'li yıllarda, özellikle batılı toplumlarda kendini göstermiştir (Friedl \& Ellis, 1976; Booth \& Edwards, 1985). Ancak bu konunun, ortalama evlenme yaşı en yüksek ve doğurganlık oranı en düşük ülkelerden biri olan Japonya için daha çok ele alındığı dikkati çekmektedir (Uchida, Araki \& Murata, 1992; Retherford, Ogawa \& Matsukura, 2004; To, 2015). Bununla birlikte literatürdeki çalışmaların çoğunluğunun betimsel istatistiklerin yer aldığ 1 demografik veya sosyolojik çalışmalardan oluştuğu; ampirik çalışmaların ise kısıtlı sayıda olduğu görülmektedir (Uchida, Araki \& Murata, 1992; Zuanna vd., 1998; Ono, 2003; Saardchom \& Lemaire, 2005). Bu bağlamda bu çalışmada Türkiye'de, evliliği erteleme ya da geç evlenme olarak adlandırılan, bireylerin evlenme yaşını öteleyen faktörlerin etkilerinin ve bu faktörlerin cinsiyet bakımından farklılıklarının yaşam analizi ile incelenmesi amaçlanmıştır. Yaşam analizi ortaya çıkan bir olayın hem zamanını hem de bu zaman üzerinde etkisi olan diğer faktörleri modele katarak araştırmaktadır. Bu çerçevede TÜİK AYA 2016 verileri içerisinde yer alan temel sosyo-ekonomik ve evlilik karar ölçeklerinden yararlanılmış olup, ortalama evlilik yaşının yükselmesinde etkisi Cox regresyon modeli üzerinden araştırılmıştır. Çalışma, ortalama evlilik yaşının yükselmesine iki açıdan yaklaşmaktadır: birincisi, Türkiye'de genel eğilimi; ikincisi ise kadın ve erkek arasındaki farklılıkların ortaya konmasıdır. Elde edilen bulgulara göre Türkiye için yaşanılan bölge, eğitim seviyesi, aile yapılarının benzerliği gibi faktörlerin evlilik yaşını oldukça etkilediği ve bununla birlikte tutumluluk, çalışma saatleri gibi ölçeklerde evlilik yaşının cinsiyete göre farklılık gösterdiği görülmüştür.

Çalışma Giriş ve Sonuç bölümleri dahil altı bölümden oluşmaktadır. İkinci bölümünde, evliliği ertelemede rolü olan faktörler incelenmiş; üçüncü ve dördüncü bölümlerde kullanılan yöntem ve araştırmanın kapsamı ile veri seti hakkında bilgi verilmiştir. Bu doğrultuda yapılan analiz sonuçları beşinci bölümde verilmiş ve çalışma, sonuç bölümü ile tamamlanmıştır.

\section{EVLİLİĞİ ERTELEMEYİ ETKİLEYEN FAKTÖRLER}

Evlilik için çok farklı gelenekler, yapılar, tanımlar bulunmakla birlikte ortak olan tek kanı evlilik kurumunun evrensel olduğudur (Bulut, 1991; Coleman, 2003; Adams, 2004). Evliliğin gerçekleşmesi, çalışmalarda bir süreç olarak ele alınmakta ve sosyolojik çalışmalara sıklıkla konu olmaktadır. Evliliğin gerçekleşmesi sürecinde yaşanılan bölge, yaş, gelir durumu gibi pek çok faktörün etkisi bulunmaktadır. Ancak, bunların içerisindeki ilk şart evliliği gerçekleştirecek tarafların kendilerini hem psikolojik hem de fiziksel olarak hazır hissetmeleridir.

Literatürde incelenen çalışmalar ile ortalama evlilik yaşının yükselmesi üzerinde etkisi olan faktörler Tablo 1'de özetlenmiştir. Tabloda yer alan çalışmalarda bireylerin yaşadıkları yerin ve bölgenin, eğitim seviyelerinin, sosyo-ekonomik durumlarının ortak olarak ele alınan faktörler olduğu dikkat çekmektedir. Özellikle Carmichael (2011) çalışmasının bulguları, eğitim düzeyinin kadınların evlenme yaşını arttırıcı anahtar değişken olduğunu ortaya koymuştur. 
Tablo 1. Literatürde Ortalama Evlilik Yaşını Yükselten Faktörleri İnceleyen Bazı Çalışmalar

\begin{tabular}{|c|c|c|}
\hline Yazar/Yazarlar & Çalışma Yılı & Vurgulanan Faktörler \\
\hline Booth \& Edwards & 1985 & Gelir seviyesi \\
\hline \multirow{3}{*}{ Uchida, Araki \& Murata } & \multirow{3}{*}{1992} & Çalışma durumu \\
\hline & & Gelir seviyesi \\
\hline & & Yaşanılan yer \\
\hline \multirow{4}{*}{ Zuanna vd. } & \multirow{4}{*}{1998} & Din \\
\hline & & Yaşanılan yer \\
\hline & & Modernleşme \\
\hline & & Eğitim seviyesi \\
\hline Ono & 2003 & Kadınların iş hayatına katılması (ekonomik gücü) \\
\hline \multirow{3}{*}{ Retherford, Ogawa \& Matsukura } & \multirow{3}{*}{2004} & Eğitim seviyesi \\
\hline & & Kadınların iş hayatına katılması \\
\hline & & Evliliğe bakışın değişmesi \\
\hline \multirow{4}{*}{ Tezcan \& Coşkun } & \multirow{4}{*}{2004} & Kadının iş hayatına katılması \\
\hline & & Kentleşme \\
\hline & & Eğitim seviyesi \\
\hline & & Yaşanılan bölge \\
\hline \multirow{3}{*}{ Mahmoodian } & \multirow{3}{*}{2005} & Eğitim seviyesi \\
\hline & & Yaşanılan yer \\
\hline & & Etnik yapı \\
\hline \multirow{3}{*}{ Saardchom \& Lemaire } & \multirow{3}{*}{2005} & Eğitim seviyesi \\
\hline & & Ekonomik modernleşme \\
\hline & & Sosyal çevre \\
\hline \multirow{2}{*}{ Jones \& Gubhaju } & \multirow{2}{*}{2009} & Eğitim seviyesi \\
\hline & & Kadının toplumda değisşen rolü \\
\hline \multirow{2}{*}{ Carmichael } & \multirow{2}{*}{2011} & Eğitim seviyesi \\
\hline & & Kentleşme \\
\hline \multirow{3}{*}{ To } & \multirow{3}{*}{2015} & Kadınların iş hayatına katılması \\
\hline & & Modernleşme \\
\hline & & Aşk \\
\hline Giddens & 2017 & Aşk \\
\hline
\end{tabular}


Kentleşmenin erkek ve kadınların ilk evlenme yaşları üzerinde hem azaltıcı hem de arttırıcı etkisi olduğunu ileri süren teoriler bulunmaktadır. Bunlardan ilki şehirleşmenin daha büyük bir evlilik piyasası yaratarak, her iki cinsiyet için de ilk evlilik yaşını düşüreceği görüşüdür. Buna karşılık diğer görüşe göre, kentleşmenin bireyleri geleneklerinden ve köklerinden koparması ve işgücüne katılım oranlarındaki yükselme ilk evlilik yaşını yükseltecektir (Carmichael, 2011: 421). Bu durum özellikle kadının toplumda değişen rolünün irdelenmesiyle birlikte pek çok çalışmada ele alınmıştır. Kentleşmeye ilave olarak, geleneksel toplumlarda evlilik kararında aşkın herhangi bir etkisi neredeyse hiç yokken; modern toplumlarda evlilik kararının altında aşk vardır. Beck ve Beck-Gernsheim evlilik bağının kurulmasında aşkın önemini ortaya koymuşlardır (Giddens, 2017: 181). Analiz sonuçlarına göre, evlenme kararı üzerinde aşkın önemli olduğunu düşünenlerin düşünmeyenlere göre evliliği erteleme riski $\% 12$ daha yüksektir.

\section{YÖNTEM}

Yaşam analizleri (survival analysis), belirlenen zaman aralığında tanımlanan bir olayın başlamasından, gerçekleşmesine kadar geçen süreye etki eden faktörleri inceleyen temel bir araştırma yöntemidir. Bu bakımdan "zaman" ve "olay" bu yöntemin en önemli unsurlarıdır. Analizin çıktı değişkeni, genel olarak, "ilgilenilen olay gerçekleşene kadarki zaman" olarak tanımlanmaktadır (Gökmen, Eralp \& Atay Kayış, 2019). Yaşam analizinde diğer yöntemlerden farklı olarak, ortaya çıkan olayın zamanının yanı sıra diğer faktörlerin de etkisi dikkate alınmakta ve bu faktörler modele katılmaktadır. Bu alandaki çalışmaların temelini Cox'un (1972) regresyon modeli ve yaşam tabloları oluşturmaktadır. İlerleyen süreçte, özellikle, Kalbfleisch ve Prentice (1973)'in literatüre katkılarıyla yaşam analizi daha çok önem kazanmıştır.

Yaşam analizindeki önemli kavramlardan bazıları, $S(t)$ yaşam fonksiyonu (survival function) ve $h(t)$ risk fonksiyonu (hazard function) kavramlarıdır. Yaşam fonksiyonu ile, gerçekleşen bir olayın belirli bir $t$ zamanından daha uzun sürece dahil olabilmesi (ilgilenilen olayın gerçekleşmemesi) olasılığı araştırılmaktadır. Bir başka deyişle, risk fonksiyonu ile ilgilenilen olayın $t$ zamanında gerçekleşmemesi olasılığı araştırılmaktadır (Kleinbaum \& Klein, 2012: 9-10). Yorumlamanın kolay olmasından dolayı bu fonksiyonların grafiğinin çizilmesi de, analizlerde sıklıkla tercih edilmektedir.

Yaşam analizinde, gerçekleşen olayın sürecine ilişkin karakteristik özellikleri tahmin etmek ve yorumlamak için Kaplan-Meier yönteminden ve grafiklerinden yararlanılmaktadır. Açıklayıcı değişken olarak ele alınan faktörler ile yaşam süreleri arasındaki yapının incelenmesi için ise Cox regresyon modeli kullanılmaktadır. Bunun nedeni, yaşam analizlerinde incelenen olayın gerçekleşmesinden dolayı veri setinden düşen gözlemlerin ve zaman kavramının analize dahil edilmesinin ancak, Cox regresyon modeli ile mümkün olmasındandır.

Yaşam süresi ile açılayıcı değişkenler arasındaki neden-sonuç ilişkisinin incelenmesinde ise s1klıkla tercih edilen Cox oransal risk regresyon (Cox proportional hazards regression) modeli, 1927 yılında David R. Cox tarafından geliştirilmiş olup, Cox regresyon modeli olarak da bilinmektedir. Cox modeli, yaşam süresinde belirli bir dağılım gerektirmediğinden yarı parametrik bir yöntemdir.

Cox regresyon modeli ile elde edilen risk fonksiyonunun tanımlanmasında, $X_{1}, X_{2}, \ldots, X_{p}$ kitle bileşenlerinin gözlenen değerleri $x_{1}, x_{2}, \ldots, x_{p}$ olmak üzere; 


$$
\lambda(t)=\lambda_{0}(t) \exp \left(\sum_{i=1}^{p} \beta_{i} x_{i}\right)
$$

ifadesi kullanılmaktadır. $\mathrm{Bu}$ model, $\beta=\left(\beta_{1}, \beta_{2}, \ldots, \beta_{p}\right)$ olmak üzere $1 \times p$ boyutundaki parametre vektörü ile log-doğrusal model olarak tanımlanmaktadır. Modelin $\lambda_{0}(t)$ ise, $x=0$ olduğu durumdaki temel risk fonksiyonu olarak tanımlanmaktadır. $\mathrm{Bu}$ modelin regresyon parametrelerinin tahmini En Çok Olabilirlik (Maximum Likelihood) yöntemi ile yapılmaktadır (Cox, 1972). Ancak, bu model için oransal risk varsayımının sağlanması gerekmektedir.

Oransal risk varsayımı, kısaca, eş değişkenlerin herhangi iki seviyesinin risk fonksiyonlarının takip eden zaman periyodunda oransal olmasıdır. Grup 1 ve 2 'nin eş değişkenler olduğu varsayıldığında; risk fonksiyonları sırasıyla $\lambda_{1}$ ve $\lambda_{2}$ olarak tanımlanırsa, her bir grup için $t$ anındaki $(t>0)$ oransal risk $\psi$,

$$
\psi=\frac{\lambda_{1}(t \mid \text { grup } 1)}{\lambda_{2}(t \mid \text { grup } 2)}
$$

şeklinde gösterilmektedir (Abeysekera \& Sooriyarachchi, 2009). Oransal risk varsayımı, $\psi$ oranının tüm $t$ değerleri için sabit olduğunu, bu oranın zamana bağlı değişemeyeceğini ifade etmektedir.

$\mathrm{Bu}$ varsayımın test edilmesi için grafiksel yaklaşımlar ve oransal-olmayanı saptamak üzerine geliştirilmiş testler mevcuttur. Grafiksel yaklaşımlarda genellikle, yaşam fonksiyonlarının log-farkları yaşam grafiği, her grup için Kaplan-Meier tahminleri ve Cox regresyon eğrisinin grafiği, farklı grupların birikimli risk grafiği, zamana karşı birikimli logrisklerin farkları grafiği, zamana karşı log-birikimli risk oranlarının yumuşatılmış grafiği, zamana karşı Schoenfeld artıklarının yumuşatılmış grafiği ve hata sayısına karşı tahmin edilen birikimli risk grafiği kullanılmaktadır. Oransal-olmayan oranı saptamak için geliştirilen testler için ise Schoenfeld kısmi artıklara dayanan test, risk oranlarının farklı genelleştirilmiş rank tahmin edicilerinin karşılaştırılmasına dayanan test ve Cox regresyon modelinin yar1-parametrik genelleştirilmesine dayanan test örnek olarak verilebilir. Literatürde buradaki yöntemlerin birinin diğerine üstünlüğünü gösteren bir çalışma bulunmamaktadır (Ata \& Sözer, 2007). Bu bakımdan tüm yöntemler, oransal risk varsayımının incelenmesinde kullanılabilmektedir. Ancak literatürde çoğunlukla, değişkenlerin Schoenfeld test sonuçlarının dikkate alındığı görülmektedir.

\section{ARAŞTIRMA KAPSAMI VE VERÍLER}

Çalışmada TÜİK'in AYA 2016 verileri kullanılmıştır. Bu veri seti içerisinde en fazla bir resmi nikah ile evlilik yapmış veya hiç evlenmemiş toplam 22.629 kişinin bilgilerinden faydalanılmıştır. Çalışmada "kişinin bitirdiği yaş" yaşam süresi değişkeni (açıklanan değişken) olarak ele alınmıştır. Bu süredeki ilgilenilen olay evliliğin ertelenmesidir. Ancak literatürde, bireylerin "kabul edilebilir" ya da "normal evlenme" yaşının ne olduğu farklılık göstermesine rağmen; hangi yaştan sonra evlenmekte geciktikleri konusunda genel bir kabul bulunmamaktadır (Canatan \& Yıldırım, 2018: 115). Bu bağlamda, çalışmada, ele alınan verilerin 2016 yılına ait olması nedeniyle, TÜiK'in aynı yı (2016) açıkladığı ortalama evlenme yaşları evliliğin ertelenmiş sayılması için sınır yaş olarak alınmıştır ve bu sınır yaşlar Türkiye geneli için 25,5 ( \pm $0,031 \mathrm{ss})$; kadınlar için 24 ( $\pm 0,043 \mathrm{ss})$ ve erkekler için $27( \pm 0,039)$ 'dur. Dolayısıyla çalışmada bu yaşların üzerinde evlenen bireyler ilgilenilen olay olarak tanımlanmıştır. Ele alınan veri 
içerisinde, genel olarak, "Türkiye'de evliliği ertelemiş" gözlemlerin oranı yaklaşık olarak \%23'tür.

Çalışmada, evlilik süresini etkileyen sosyo-ekonomik faktörler, Tablo 1'de yer alan çalışmalardan yola çıkarak belirlenmiştir. Ayrıca literatürdeki araştırmalardan farklı olarak, AYA 2016 çalışmasında yer alan evlilik karar ölçekleri hem Türkiye geneli hem de cinsiyet bakımından ayrı ayrı incelenmiştir.

\section{BULGULAR}

Çalışmada belirlenen değişkenler ve ölçekler bakımından Türkiye geneli, kadınlar ve erkekler için Cox modeli ile parametre tahminleri yapılmıştır. Bu analizler için STATA paket programlarından faydalanılmıştır. $\mathrm{Bu}$ aşamada, modelin kullanılabilmesi için gerekli olan oransal risk varsayımı Schoenfeld artıklarına ilişkin test ile incelenmiştir. Bu testin sonuçlarına göre değişkenlerin varsayımı sağladığı görülmüştür. Hem cinsiyet farkını dikkate almayan genel modelin hem de cinsiyet üzerinden tahminleri yapılan modellerin olabilirlik oran testi p-değerleri 0,05'den küçük olduğundan her üç modelin de istatistiksel olarak anlamlı olduğu söylenebilir.

Cox modellerinin ele alınan sosyo-ekonomik değişkenler üzerinden tahmin edilen parametreleri Tablo 2'de verilmiştir. Ortalama evlilik yaşının yükselmesi, sosyo-ekonomik değişkenler bakımından incelendiğinde en dikkat çeken nokta, eğitim seviyesi olduğu görülmektedir. Buna göre, Türkiye genelinde, yalnızca ilkokul bitiren bireylerin dahi hiç okul okumamış bireylere göre evliliği erteleme olasılıkları yaklaşık 2,5 kat yükselmektedir. Bu oran lisansüstü eğitim almış bireylerde yaklaşık 4 kattır. Bununla beraber, özellikle kadınların evliliği erteleme olasılıkları erkeklere göre çok daha yüksektir. Lisansüstü eğitim almış bir kadının, hiç okula gitmemiş hemcinsine göre evliliği erteleme olasılı̆̆ yaklaşı 6,6 kat artarken; bu oran erkekler için yaklaşık 1,17 'dir.

Yaşanılan bölge incelendiğinde, kentte yaşamanın kırsal bölgede yaşamaya göre bireylerin ilk evlilik yaşını yükseltmesi olasılığını yaklaşık 0,96 kat arttırdığı söylenebilir. Kadınlar için bu oran yaklaşık 0,56 iken, erkekler içinse bu oran çok daha yüksek $(1,63)$ tahmin edilmiştir. Diğer bir ifadeyle kentte yaşayan erkeklerin kadınlara göre evliliği ileri yaşa erteleme olasılıklarının daha yüksek olduğu söylenebilir. Yaşanılan bölge açısından, genel olarak, birçok bölgede yaşamanın İstanbul'da yaşayan bireylere göre (hem genel hem cinsiyet için) evlenme yaşını yükseltme riskini düşürdügü gözlenmiştir. Bu oran yalnızca Kuzeydoğu, Ortadoğu ve Güneydoğu Anadolu bölgelerinde yükselmektedir. Bu durumun, bu bölgelerin yapılarında meydana gelen bir değişimden kaynaklı olup olmadıklarını ayrıca incelemek gerekmektedir. Buna karşılık, bölge açısından cinsiyetler arasında büyük bir farklılık görülmemiştir.

Bireylerin çalışma durumu, evliliğe ekonomik açıdan hazır olmanın öncelikli şartlarından biri olarak görüldüğü söylenebilir. Buna karşılık, Türkiye'de yaşayan bireylerin çalışıyor olmasının çalışmayan bireylere göre ilk evlilik yaşını erteleme olasılıklarını yaklaşık 0,30 arttırdığı görülmektedir. Kadınlar için bu değişkene ilişkin parametre tahmini istatistiksel olarak anlamsız iken, erkekler için bu oran yaklaşık 0,76'ya yükselmektedir. Türkiye'de 2016 yılı kadınların işgücüne katılım oranı \%36,2'dir. Dolayısıyla kadınlar için bu durumun istatistiksel olarak anlamlı olmamasının nedeni, erkeklere göre $(\% 77,6)$ çalışma hayatına katılımlarının düşüklügü gösterilebilir¹. Erkeklerin ilk evlenme yaşını yükselten bir faktör olan "çalışıyor olma durumu", günümüzde evlenmek ya da ideal bir yaşam sürmek için yalnızca gelir sahibi olmanın yeterli olmadığının, genellikle belirli bir yaşam standardının sağlanmak istemesinin bir göstergesi olarak düşünülebilir.

1 TÜIK (2016), 15-64 Yaş Grubundaki Nüfusun Yıllara ve Cinsiyete Göre İşgücü Durumu. 
Tablo 2. Sosyo-ekonomik Değişkenler Bakımından Cox Regresyon Modelinin Tahmin Sonuçları

\begin{tabular}{|c|c|c|c|}
\hline Değişken & $\begin{array}{c}\text { GENEL } \\
\text { Risk Oranı }\left(\boldsymbol{e}^{\widehat{\boldsymbol{\beta}}}\right)\end{array}$ & $\begin{array}{c}\text { KADIN } \\
\text { Risk Oranı }\left(e^{\widehat{\boldsymbol{\beta}}}\right)\end{array}$ & $\begin{array}{c}\text { ERKEK } \\
\text { Risk Oranı }\left(\boldsymbol{e}^{\widehat{\boldsymbol{\beta}}}\right)\end{array}$ \\
\hline Çalışma durumu (Çalışmıyor) & $\begin{array}{c}1,310 \\
(0,009)^{*} \\
\end{array}$ & $\begin{array}{c}0,828 \\
(0,249) \\
\end{array}$ & $\begin{array}{c}1,715 \\
(0,000)^{*} \\
\end{array}$ \\
\hline \multicolumn{4}{|l|}{ Eğitim (Bir okul bitirmedi) } \\
\hline $\begin{array}{l}\text { İlkokul/genel/mesleki/teknik ortaokul veya } \\
\text { ilköğretim }\end{array}$ & $\begin{array}{c}3,512 \\
(0,000)^{*}\end{array}$ & $\begin{array}{c}3,282 \\
(0,000)^{*}\end{array}$ & $\begin{array}{c}3,083 \\
(0,000)^{*}\end{array}$ \\
\hline Genel/mesleki/teknik lise & $\begin{array}{c}5,488 \\
(0,000)^{*}\end{array}$ & $\begin{array}{c}6,236 \\
(0,000)^{*}\end{array}$ & $\begin{array}{c}3,546 \\
(0,000)^{*}\end{array}$ \\
\hline Yüksekokul & $\begin{array}{c}4,607 \\
(0,000)^{*}\end{array}$ & $\begin{array}{c}6,194 \\
(0,000)^{*}\end{array}$ & $\begin{array}{c}2,409 \\
(0,000)^{*}\end{array}$ \\
\hline Dört yıllık yüksekokul veya fakülteler & $\begin{array}{c}5,327 \\
(0,000)^{*}\end{array}$ & $\begin{array}{c}7,767 \\
(0,000)^{*}\end{array}$ & $\begin{array}{c}2,755 \\
(0,000)^{*}\end{array}$ \\
\hline Lisansüstü & $\begin{array}{c}5,008 \\
(0,000)^{*}\end{array}$ & $\begin{array}{c}7,607 \\
(0,000)^{*}\end{array}$ & $\begin{array}{c}2,174 \\
(0,029) *\end{array}$ \\
\hline Yaşanılan yer (Kır) & $\begin{array}{c}1,959 \\
(0,000)^{*}\end{array}$ & $\begin{array}{c}1,564 \\
(0,000)^{*}\end{array}$ & $\begin{array}{c}2,631 \\
(0,000)^{*}\end{array}$ \\
\hline \multicolumn{4}{|l|}{ Yaşanılan Bölge (İstanbul (TR1)) } \\
\hline Bat1 Marmara (TR2) & $\begin{array}{c}0,881 \\
(0,057)^{* *}\end{array}$ & $\begin{array}{c}0,911 \\
(0,285)\end{array}$ & $\begin{array}{c}0,759 \\
(0,009)^{*}\end{array}$ \\
\hline Ege (TR3) & $\begin{array}{c}0,849 \\
(0,001)^{*}\end{array}$ & $\begin{array}{c}0,874 \\
(0,037)^{*}\end{array}$ & $\begin{array}{c}0,709 \\
(0,000)^{*}\end{array}$ \\
\hline Doğu Marmara (TR4) & $\begin{array}{c}0,839 \\
(0,002)^{*}\end{array}$ & $\begin{array}{c}0,928 \\
(0,304)\end{array}$ & $\begin{array}{c}0,743 \\
(0,001)^{*}\end{array}$ \\
\hline Bat1 Anadolu (TR5) & $\begin{array}{c}0,869 \\
(0,005)^{*}\end{array}$ & $\begin{array}{c}0,894 \\
(0,080)^{* *}\end{array}$ & $\begin{array}{c}0,837 \\
(0,026) *\end{array}$ \\
\hline Akdeniz (TR6) & $\begin{array}{c}1,162 \\
(0,003)^{*}\end{array}$ & $\begin{array}{c}1,221 \\
(0,003)^{*}\end{array}$ & $\begin{array}{c}1,102 \\
(0,221)\end{array}$ \\
\hline Orta Anadolu (TR7) & $\begin{array}{c}1,129 \\
(0,045)^{*}\end{array}$ & $\begin{array}{c}1,213 \\
(0,012)^{*}\end{array}$ & $\begin{array}{c}1,108 \\
(0,303)\end{array}$ \\
\hline Batı Karadeniz (TR8) & $\begin{array}{c}0,914 \\
(0,160)\end{array}$ & $\begin{array}{c}1,006 \\
(0,932)\end{array}$ & $\begin{array}{c}0,777 \\
(0,016)^{*}\end{array}$ \\
\hline Doğu Karadeniz (TR9) & $\begin{array}{c}1,077 \\
(0,306)\end{array}$ & $\begin{array}{c}1,180 \\
(0,075)^{* *}\end{array}$ & $\begin{array}{c}1,049 \\
(0,678)\end{array}$ \\
\hline Kuzeydoğu Anadolu (TRA) & $\begin{array}{c}1,430 \\
(0,000)^{*}\end{array}$ & $\begin{array}{c}1,667 \\
(0,000)^{*}\end{array}$ & $\begin{array}{c}1,271 \\
(0,048)^{*}\end{array}$ \\
\hline Ortadoğu Anadolu (TRB) & $\begin{array}{c}1,512 \\
(0,000)^{*}\end{array}$ & $\begin{array}{c}1,737 \\
(0,000)^{*}\end{array}$ & $\begin{array}{c}1,315 \\
(0,004)^{*}\end{array}$ \\
\hline Güneydoğu Anadolu (TRC) & $\begin{array}{c}1,709 \\
(0,000)^{*}\end{array}$ & $\begin{array}{c}2,019 \\
(0,000)^{*}\end{array}$ & $\begin{array}{c}1,502 \\
(0,000)^{*}\end{array}$ \\
\hline
\end{tabular}

Parantez içleri p-değerlerini göstermektedir.

* Bu katsayılar 0,01 ve 0,05 hata payı ile istatistiksel olarak anlamlıdır.

* *Bu katsayılar 0,10 hata payı ile istatistiksel olarak anlamlıdır.

Evlilik yaşının yükselmesinde sosyo-ekonomik etkenler kadar bireylerin karşı taraftan beklentileri de oldukça önemli bir rol oynamaktadır. Bu bağlamda, evlilik karar ölçeklerine ilişkin Cox modellerinin parametre tahminleri Tablo 3'de verilmiştir ${ }^{2}$. Evlilik karar ölçeklerine ilişkin tahmin sonuçları incelendiğinde, 7, 11, 12, 14, 19, 20, 21 ve 25 numaralı ölçeklerin hem genel modelde hem de cinsiyete dayalı modellerde tahmin edilen katsayılarının istatistiksel olarak anlamsız olduğu görülmektedir.

Türkiye geneli için istatistiksel olarak anlamlı bulunan ölçekler incelendiğinde, evlenilecek bireyin iyi eğitimli olması, çalışma saatlerinin az olması, ilk kez evlilik yapacak

\footnotetext{
${ }^{2}$ Tablo 3, Tablo 2'nin devamıdır. Ele alınan değişkenlerin ve ölçeklerin daha anlaşılır yorumlanabilmesi bakımından ayrı ayrı tablolaştırılmıştır.
} 
olması, nikahsız birlikte yaşamayı önemsemesi, internette tanışmış olması, aşık olması, güzel/yakışıklı olması, karşı tarafın duygularına önem vermesi, cömert olması ve toplum içinde nasıl davranacağını bilmesi evliliği erteleme riskini yükselten faktörler olarak görülmektedir. $\mathrm{Bu}$ faktörlerin içindeki en büyük etkenin "aşk" olduğu dikkati çekmektedir. Bu sonuca göre evlilik için aşkı önemseyen bireylerin, önemsemeyen bireylere göre ilk evlilik kararını erteleme olasılıkları yaklaşık 0,60 artmaktadır. Günümüzde bireylerin evlilik için aşkı bekliyor olması, Giddens'1n (2017) bulgularıyla da örtüşmektedir. Bu etkeni, internette tanışılan bireyin olması ve cömertlik takip etmektedir. Buna karş1lık evliliği erteleme riskini düşüren ölçeklerin ise; karş1 tarafin işinin olması, ailelerin benzer yapıda olması, aynı mezhepten/memleketten/sosyal çevreden olması ve eşini kendi ailesine ezdirememesi ölçekleri olduğu görülmektedir. Bu ölçekler arasında ise, evliliği erteleme riskini en çok düşüren faktör aile yapılarının benzer olmasıdır. Buna göre, aile yapısının benzerliğini önemseyen bireylerin, önemsemeyen bireylere göre evliliği erteleme riski yaklaşık 0,30 düşmektedir. Bu oranı, evliliği erteleme riskini yaklaşık 0,26 düşüren, "evlenilecek bireyin işinin olması" ve "bireyin eşini kendi ailesine ezdirmemesi" ölçekleri takip etmektedir.

Cinsiyete göre tahmin edilen modeller incelendiğinde evliliğin ertelenme riskini düşüren faktörlerin Türkiye geneli için tahmin edilen modelle büyük ölçüde benzer olduğu görülmüsstür. Buna karş1lık özellikle "karşı tarafın işinin olması" ölçeği incelendiğinde, tahmin edilen parametre değerlerine göre bu değişken, kadınlar bakımından evliliğin ertelenmesi riskini arttırırken; erkekler bakımından riski düşürücü etki göstermektedir. Bu durum, kadınların iş hayatında bireyselleşmekle birlikte, yine de erkeğe bağl1lığının bu noktada devam ettiğinin bir göstergesi olarak yorumlanabilir. Erkekler bakımından, çalışan eş adayının evliliği erteleme riskini düşürdüğü görülmektedir. Kadın ve erkek arasında gözlenen bir diğer fark ise; kadınların cömert bir eş için evliliği ertelemeyi göze almadığı, buna karşılık erkeklerin ise tutumlu eş için evliliği ertelemeyi göze almadığı görülmektedir. Kadınlar için; eşin iyi eğitimli olması, aşık olması, güzel/yakışıklı olması, cömert olması ve toplum içinde nasıl davranacağını bilmesi ilk evlilik yaşının yükselmesinde etkisi olan faktörlerdir. Bu faktörler erkekler içinse; eşin çalışma saatlerinin az olması, ilk kez evlenecek olması, nikahsız birlikte yaşamayı önemsemesi, aş1k olması ve güzel/yakışıklı olmasıdır. Evliliğin ertelenme riskini yükselten ortak faktörler içerisinde, "eşin âşı olmasının" erkekler için yaklaşık 0,20 daha fazla önem taşıdığı görülmektedir.

Tablo 3. Sosyo-ekonomik Değişkenler Bakımından Cox Regresyon Modelinin Tahmin Sonuçları

\begin{tabular}{|c|c|c|c|}
\hline Değişken & $\begin{array}{c}\text { GENEL } \\
\text { Risk Oranı }\left(\boldsymbol{e}^{\widehat{\boldsymbol{\beta}}}\right)\end{array}$ & $\begin{array}{c}\text { KADIN } \\
\text { Risk Oranı }\left(e^{\widehat{\boldsymbol{\beta}}}\right)\end{array}$ & $\begin{array}{c}\text { ERKEK } \\
\text { Risk Oranı }\left(e^{\widehat{\beta}}\right)\end{array}$ \\
\hline $\begin{array}{l}\text { Ö1: Size göre, evlenilecek bireyin iyi eğitimli } \\
\text { olması ne kadar önemlidir? }\end{array}$ & $\begin{array}{c}1,121 \\
(0,001)^{*}\end{array}$ & $\begin{array}{c}1,124 \\
(0,009)^{*}\end{array}$ & $\begin{array}{c}1,024 \\
(0,648)\end{array}$ \\
\hline $\begin{array}{l}\text { Ö2: Size göre, evlenilecek bireyin yüksek gelir } \\
\text { sahibi/ varlıklı olması ne kadar önemlidir? }\end{array}$ & $\begin{array}{c}0,981 \\
(0,509)\end{array}$ & $\begin{array}{c}1,034 \\
(0,342)\end{array}$ & $\begin{array}{c}0,885 \\
(0,022)^{*}\end{array}$ \\
\hline $\begin{array}{l}\text { Ö3: Size göre, evlenilecek bireyin bir işinin olması } \\
\text { ne kadar önemlidir? }\end{array}$ & $\begin{array}{c}0,736 \\
(0,000)^{*}\end{array}$ & $\begin{array}{c}1,213 \\
(0,008)^{*}\end{array}$ & $\begin{array}{c}0,699 \\
(0,000)^{*}\end{array}$ \\
\hline $\begin{array}{l}\text { Ö4: Size göre, evlenilecek bireyin çalışma } \\
\text { saatlerinin az olması ne kadar önemlidir? }\end{array}$ & $\begin{array}{c}1,112 \\
(0,000)^{*}\end{array}$ & $\begin{array}{c}1,042 \\
(0,256)\end{array}$ & $\begin{array}{c}1,223 \\
(0,000)^{*}\end{array}$ \\
\hline $\begin{array}{l}\text { Ö5: Size göre, evlenilecek bireyin ilk kez evlenecek } \\
\text { olması ne kadar önemlidir? }\end{array}$ & $\begin{array}{c}1,241 \\
(0,000)^{*}\end{array}$ & $\begin{array}{c}1,256 \\
(0,000)^{*}\end{array}$ & $\begin{array}{c}1,132 \\
(0,056) * * \\
\end{array}$ \\
\hline $\begin{array}{l}\text { Ö6: Size göre, evlenilecek bireyin aile yapılarının } \\
\text { benzer olması ne kadar önemlidir? }\end{array}$ & $\begin{array}{c}0,697 \\
(0,000)^{*}\end{array}$ & $\begin{array}{c}0,675 \\
(0,000)^{*}\end{array}$ & $\begin{array}{c}0,699 \\
(0,000)^{*}\end{array}$ \\
\hline $\begin{array}{l}\text { Ö8: Size göre, evlenilecek bireyin aynı mezhepten } \\
\text { olması ne kadar önemlidir? }\end{array}$ & $\begin{array}{c}0,876 \\
(0,000)^{*} \\
\end{array}$ & $\begin{array}{c}0,858 \\
(0,000)^{*} \\
\end{array}$ & $\begin{array}{c}0,943 \\
(0,289) \\
\end{array}$ \\
\hline
\end{tabular}


Tablo 3. (Devam) Sosyo-ekonomik Değişkenler Bakımından Cox Regresyon Modelinin Tahmin Sonuçları

\begin{tabular}{|c|c|c|c|}
\hline Değişken & $\begin{array}{c}\text { GENEL } \\
\text { Risk Oranı }\left(e^{\widehat{\beta}}\right)\end{array}$ & $\begin{array}{c}\text { KADIN } \\
\text { Risk Oranı }\left(e^{\widehat{\beta}}\right)\end{array}$ & $\begin{array}{c}\text { ERKEK } \\
\text { Risk Oranı }\left(e^{\widehat{\beta}}\right)\end{array}$ \\
\hline $\begin{array}{l}\text { Ö9: Size göre, evlenilecek bireyin ayn1 } \\
\text { memleketten/ hemșeri olması ne kadar önemlidir? }\end{array}$ & $\begin{array}{c}0,781 \\
(0,000)^{*}\end{array}$ & $\begin{array}{c}0,770 \\
(0,000)^{*}\end{array}$ & $\begin{array}{c}0,825 \\
(0,002)^{*}\end{array}$ \\
\hline $\begin{array}{l}\text { Ö10: Size göre, evlenilecek bireyin aynı sosyal } \\
\text { çevreden olması ne kadar önemlidir? }\end{array}$ & $\begin{array}{c}0,877 \\
(0,000)^{*}\end{array}$ & $\begin{array}{c}0,887 \\
(0,004)^{*}\end{array}$ & $\begin{array}{c}0,815 \\
(0,000)^{*}\end{array}$ \\
\hline $\begin{array}{l}\text { Ö11: Size göre, evlenilecek bireyin aynı etnik } \\
\text { kökenden olması ne kadar önemlidir? }\end{array}$ & $\begin{array}{c}0,993 \\
(0,842) \\
\end{array}$ & $\begin{array}{c}1,026 \\
(0,531) \\
\end{array}$ & $\begin{array}{c}0,933 \\
(0,214) \\
\end{array}$ \\
\hline $\begin{array}{l}\text { Ö12: Size göre, evlenilecek bireyin benzer siyasi } \\
\text { görüşe sahip olması ne kadar önemlidir? }\end{array}$ & $\begin{array}{c}0,994 \\
(0,854)\end{array}$ & $\begin{array}{c}0,975 \\
(0,487)\end{array}$ & $\begin{array}{c}1,145 \\
(0,007) *\end{array}$ \\
\hline $\begin{array}{l}\text { Ö13: Çiftler nikahsız (resmi veya dini) olarak } \\
\text { birlikte yaşayabilir mi? }\end{array}$ & $\begin{array}{c}1,178 \\
(0,003)^{*}\end{array}$ & $\begin{array}{c}1,081 \\
(0,333)\end{array}$ & $\begin{array}{c}1,273 \\
(0,002)^{*}\end{array}$ \\
\hline Ö14: Çiftler, evlilik dışı çocuk sahibi olabilir mi? & $\begin{array}{c}0,938 \\
(0,346) \\
\end{array}$ & $\begin{array}{c}0,977 \\
(0,815) \\
\end{array}$ & $\begin{array}{c}0,858 \\
(0,106) \\
\end{array}$ \\
\hline $\begin{array}{l}\text { Ö15: İnternette tanış1lan birisiyle evlilik yapılabilir } \\
\text { mi? }\end{array}$ & $\begin{array}{c}1,473 \\
(0,000)^{*} \\
\end{array}$ & $\begin{array}{c}1,453 \\
(0,000)^{*} \\
\end{array}$ & $\begin{array}{c}1,479 \\
(0,000)^{*} \\
\end{array}$ \\
\hline $\begin{array}{l}\text { Ö16: Size göre, evlenilecek bireyin size aş1k olması } \\
\text { ne kadar önemlidir? }\end{array}$ & $\begin{array}{c}1,626 \\
(0,000)^{*}\end{array}$ & $\begin{array}{c}1,496 \\
(0,000)^{*}\end{array}$ & $\begin{array}{c}1,869 \\
(0,000) *\end{array}$ \\
\hline $\begin{array}{l}\text { Ö17: Size göre, evlenilecek bireyin güzel/ yakışıklı } \\
\text { olması ne kadar önemlidir? }\end{array}$ & $\begin{array}{c}1,248 \\
(0,000) *\end{array}$ & $\begin{array}{c}1,209 \\
(0,000)^{*}\end{array}$ & $\begin{array}{c}1,253 \\
(0,000) *\end{array}$ \\
\hline $\begin{array}{l}\text { Ö18: Size göre, evlenilecek bireyin kendine özen } \\
\text { göstermesi (temizliğine dikkat etmesi) ne kadar } \\
\text { önemlidir? }\end{array}$ & $\begin{array}{c}1,050 \\
(0,462)\end{array}$ & $\begin{array}{c}0,918 \\
(0,327)\end{array}$ & $\begin{array}{c}1,111 \\
(0,310)\end{array}$ \\
\hline $\begin{array}{l}\text { Ö19: Size göre, evlenilecek kişinin eşine sadık } \\
\text { kalması ne kadar önemlidir? }\end{array}$ & $\begin{array}{c}0,791 \\
(0,087)^{* *} \\
\end{array}$ & $\begin{array}{c}0,790 \\
(0,219) \\
\end{array}$ & $\begin{array}{c}0,852 \\
(0,430) \\
\end{array}$ \\
\hline $\begin{array}{l}\text { Ö20: Size göre, evlenilecek kişinin ailesiyle vakit } \\
\text { geçirmeyi sevmesi ne kadar önemlidir? }\end{array}$ & $\begin{array}{c}0,908 \\
(0,249) \\
\end{array}$ & $\begin{array}{c}0,937 \\
(0,589) \\
\end{array}$ & $\begin{array}{c}0,968 \\
(0,789) \\
\end{array}$ \\
\hline $\begin{array}{l}\text { Ö21: Size göre, evlenilecek kişinin güvenilir kişi } \\
\text { olmas1, yalan söylememesi ne kadar önemlidir? }\end{array}$ & $\begin{array}{c}1,124 \\
(0,529)\end{array}$ & $\begin{array}{c}0,984 \\
(0,952)\end{array}$ & $\begin{array}{c}0,886 \\
(0,639)\end{array}$ \\
\hline $\begin{array}{l}\text { Ö22: Size göre, evlenilecek kişinin karş1 tarafın } \\
\text { duygularına önem vermesi ne kadar önemlidir? }\end{array}$ & $\begin{array}{c}1,411 \\
(0,021)^{*}\end{array}$ & $\begin{array}{c}1,429 \\
(0,108) \\
\end{array}$ & $\begin{array}{c}1,578 \\
(0,030)^{*} \\
\end{array}$ \\
\hline $\begin{array}{l}\text { Ö23: Size göre, evlenilecek kişinin tutumlu olması } \\
\text { ne kadar önemlidir? }\end{array}$ & $\begin{array}{c}0,946 \\
(0,378) \\
\end{array}$ & $\begin{array}{c}1,059 \\
(0,456) \\
\end{array}$ & $\begin{array}{c}0,778 \\
(0,020)^{*} \\
\end{array}$ \\
\hline $\begin{array}{l}\text { Ö24: Size göre, evlenilecek kişinin cömert olması } \\
\text { ne kadar önemlidir? }\end{array}$ & $\begin{array}{c}1,188 \\
(0,005)^{*} \\
\end{array}$ & $\begin{array}{c}1,299 \\
(0,002)^{*} \\
\end{array}$ & $\begin{array}{c}1,137 \\
(0,174) \\
\end{array}$ \\
\hline $\begin{array}{l}\text { Ö25: Size göre, evlenilecek kişinin sabırlı ve } \\
\text { hoşgörülü olması ne kadar önemlidir? }\end{array}$ & $\begin{array}{c}0,887 \\
(0,357)\end{array}$ & $\begin{array}{c}0,797 \\
(0,247)\end{array}$ & $\begin{array}{c}1,009 \\
(0,957)\end{array}$ \\
\hline $\begin{array}{l}\text { Ö26: Size göre, evlenilecek kişinin eşini kendi } \\
\text { ailesine ezdirmemesi ne kadar önemlidir? }\end{array}$ & $\begin{array}{c}0,703 \\
(0,000) * \\
\end{array}$ & $\begin{array}{c}0,588 \\
(0,001)^{*} \\
\end{array}$ & $\begin{array}{c}0,842 \\
(0,171) \\
\end{array}$ \\
\hline $\begin{array}{l}\text { Ö27: Size göre, evlenilecek kişinin toplum içinde } \\
\text { nasıl davranacağını bilmesi ne kadar önemlidir? }\end{array}$ & $\begin{array}{c}1,325 \\
(0,041)^{*}\end{array}$ & $\begin{array}{c}1,623 \\
(0,015)^{*}\end{array}$ & $\begin{array}{c}1,003 \\
(0,986)\end{array}$ \\
\hline \multicolumn{4}{|c|}{$\begin{array}{l}\text { Parantez içleri p-değerlerini göstermektedir. } \\
\text { Tüm ölçekler için referans grup "önemsiz" görüşü; incelenen grup ise "önemli” olduğu görüşüdür. } \\
\text { * Bu katsayılar } 0,01 \text { ve } 0,05 \text { hata payı ile istatistiksel olarak anlamlıdır. } \\
\text { * *Bu katsayılar } 0,10 \text { hata payı ile istatistiksel olarak anlamlıdır. }\end{array}$} \\
\hline
\end{tabular}

\section{SONUÇ}

Günümüzde ortalama evlilik yaşının yükselmesi, sıklıkla ele alınan bir sorun haline gelmiştir ve birçok toplumsal yansıması bulunmaktadır. TÜİK verilerine göre, Türkiye'de kaba evlenme hızının 2018 yılı itibariyle 6,8'e düşmesi ve ortalama evlenme yaşının her iki cinsiyet için de 25 yaşı geçtiği gözlenmiştir. Dolayısıyla, Türkiye açısından ortalama evlilik yaşının yükselmesinin toplumsal bir sorun haline dönüşme sürecine girdiği, hatta bir gerçek olarak karşımıza çıktığı söylenebilir. 
Çalışmada TÜİK Aile Yapısı Araştırması 2016 verileri kullanılarak Türkiye'nin genelini kapsayan geniş bir veri seti ile hem Türkiye geneli hem de kadın ve erkek için ilk evlenme sürecini etkileyen faktörler yaşam analizi ile araştırılmıştır. Çalışmadan elde edilen bulgulardan en çarpıc1 olanı, eğitim seviyesinin cinsiyetler arasında evliliği ertelemede farklı etkilerinin olmasıdır. Kadınlarda eğitim seviyesinin yükselmesi ile evliliğin ertelenme riski erkeklere göre daha çok yükselmektedir. Benzer olarak; karşı tarafin tutumlu olması, cömert olması, eşini kendi ailesine ezdirmemesi, toplum içinde nasıl davranacağını bilmesi, yüksek gelir sahibi olması, iyi eğitimli olması ve çalışma saatlerinin az olması ölçeklerinin cinsiyetler arasında farklılık gösteren faktörler olduğu görülmüştür. Buna karş1lık, aile yapılarının veya sosyal çevrelerinin benzer olması her iki cinsiyet için de evliliğin ertelenmesi riskini düşürdüğ̈ gözlenmiştir.

Çalışmada elde edilen bulgular literatürdeki diğer çalışmalarla uyumlu olup, özellikle kadınların bireyselleşmeye daha eğilimli olduğu ve dolayısıyla bunun evliliği erteleme üzerinde olumsuz etkileri olduğu işaret ettiği söylenebilir. Buna karşılık erkeklerin tutumlu ve az çalışma saati olan eş ile ve kadınların ise cömert ve kendini eşin ailesine ezdirmeyen eş ile evliliği erteleme riskinin düşmesi Türkiye'deki geleneksel aile yapısının korunduğunun bir göstergesi olarak ele alınabilir.

Sonuç olarak, ele alınan değişkenler bakımından Türkiye'de ilk evlilik yaşını etkileyen en önemli faktörün eğitim olduğu tespit edilmiştir. Genel bir değerlendirme yapıldığında, Türk toplumunun evlilik kurumuna bakış açısının geleneksel yapısını korumaya devam ettiği; buna karşılık aşk, kentsel yaşam, kadının iş hayatına katılması gibi faktörlerin batılı toplumlarla benzer olarak evliliğin ertelenmesi riskini cinsiyet bakımından istatistiksel olarak etkileyen ve yükselten faktörler olarak karşımıza çıkmaktadır.

Çalışma sonuçları, Türk toplumunun geleneksel aile birlikteliğinin kurulmasında etkisinin devam etmekle birlikte; eğitim, iş hayatına katılım gibi faktörler ile batılı toplumların izlediği yolu takip ettiği ya da benzediği ortaya konulmuştur. Dolayısıyla, toplumda bir dönüşüm olduğu açıktır. Bu dönüşümün dinamiklerinin zaman boyutu da dikkate alınarak incelenmesi; toplumsal yapının dinamik tutulmasında uygulanabilecek politikaların belirlenmesinde daha etkin olacaktır.

\section{KAYNAKÇA}

Abeysekera, W. \& Sooriyarachchi, M. R. (2009). Use of Schoenfeld's global test to test the proportional hazards assumption in the Cox proportional hazards model: An application to a clinical study. Journal of National Scientific Foundation, 37(1), 41-51.

Adams, N. B. (2004). Families and family study in international perspective. Journal of Marriage and Family, Vol. $66,1076-1088$.

ASPB. (2011). Türkiye'de aile yapısı araştırması 2011, Ankara: T.C. Aile ve Sosyal Politikalar Bakanlığı.

Ata, N., \& Sözer, M. T. (2007). Cox regression models with nonproportional hazards applied to lung cancer survival data. Hacettepe Journal of Mathematics and Statistics, 36(2), 157-167.

Aydın, M. (2017). Kurumlar Sosyolojisi Kurumlara Başlangıç Çerçevesinde Bir Çalışma, Açılım Kitap.

Booth, A. \& Edwards, J. N. (1985). Age at marriage and marital instability. Journal of Marriage and Family, 47(1), 67-75.

Bulut, I. (1991). Türkiye'de erken evlenme" içinde aile ansiklopedisi (Cilt 2). T.C. Başbakanlık Araştırma Kurumu Yayınları, Genel yayın no: 72, Bilim Serisi 11; s. 494-508.

Canatan, K. \& Yıldırım, E. (2018). Aile Sosyolojisi, İstanbul: Açılım Kitap.

Carmichael, S. (2011). Marriage and power: Age at first marriage and spousal age gap in lesser developed countries. The History of the Family, 16(4), 416-436. 
Coleman, D.A. (2003). Partner choice and the growth of ethnic minority populations. Marriage in Multi-Ethnic Society, Netherlands Demographic Society Annual Conference, Het Trippenhuis, Amsterdam.

Cox, D. R. (1972). Regression models and life-tables. Journal of the Royal Statistical Society-Series B (Methodological), 34(2), 187-220.

Erkal, M. E. (2016). Sosyoloji (Toplumbilimi), DER Yayınları.

Friedl, J. \& Ellis, W. (1976). Celibacy, Late marriage and potential mates in a Swiss isolate. Human Biology, 48(1), 23-35.

Giddens, A. (2017). Sosyoloji başlangıç okumaları (6. Baskı, Çeviri Günseli Altaylar). İstanbul: Say Yayınları.

Gökmen, Ş., Eralp, A. ve Atay Kayış, A. (2019). İlk evlilik süresini etkileyen faktörlerin yaşam analizi: türkiye örneği, Optimum Ekonomi ve Yönetim Bilimleri Dergisi, 2019, 6(1), 63-76.

Jones, G. W. \& Gubhaju, B. (2009) Factors influencing changes in mean age at first marriage and proportions never marrying in the lowfertility countries of east and southeast Asia. Asian Population Studies, 5(3), 237-265.

Kalbfleisch, J. D. \& Prentice, R. L. (1973). Marginal likelihoods based on Cox's regression and life model. Biometrika, 60, 267-278.

Kleinbaum, D. G. \& Klein, M. (2012). Survival analysis: a self-learning text (3rd Edition). USA: Springer.

Mahmoodian H. (2005). The increasing age at marriage: examining the protective factors. Nameh-Ye Olum-E Ejtemai, 24, 27-54.

OECD (2019). Family Database, http://www.oecd.org/els/family/database.htm , Erişim Tarihi: 03.01.2020.

Ono, H. (2003). Women's economic standing, marriage timing and cross-national contexts of gender. Journal of Marriage and Family, 65(2), 275-286.

Retherford, R. D., Ogawa, N. \& Matsukura, R. (2004). Late marriage and less marriage in Japan. Population and Development Review, 27(1), 65-102.

Saardchom, N. \& Lemaire, J. (2005). Causes of increasing ages at marriage: An international regression study. Marriage \& Family Review, 37(3), 73-97,

Tezcan, S. \& Coşkun, Y. (2004). Türkiye'de 20. yüzyılın son çeyreğinde kadınlarda ilk evlenme yaşı değiş̧imi ve günümüz evlilik özellikleri. Turkish Journal of Population Studies, 26, 15-34.

TNSA (2008). Türkiye Nüfus ve Sağllk Araştırması. Ankara: Hacettepe Üniversitesi Nüfus Etütleri Enstitüsü (HÜNEE), Sağlık Bakanlığı ACSAP Genel Müdürlüğü, Devlet Planlama Teşkilatı Müsteşarlığı ve TÜBİTAK.

To, S. (2015). China's leftover women: Late marriage among professional women and its consequences. New York: Routledge.

Turğut, M. \& Feyzioğlu, S. (Editörler) (2014). Türkiye aile yapısı araştırması tespitler, öneriler. Ankara: T.C. Aile ve Sosyal Politikalar Bakanlığı.

TÜİK (2016), Aile Yapısı Araştırması (AYA), Erişim tarihi: 20.06.2018.

Uchida, E., Araki, S. \& Murata, K. (1992). Socioeconomic factors affecting first marriage and birth rates by sex and age in the total Japanese population. PubMed, 21(2), 107-118.

Zuanna, G. D., Atoh, M., Castiglioni, M. \& Kojima, K. (1998). Late marriage among young people: the case of Italy and Japan. Genus, 54(3/4), 187-232. 


\section{EKLER:}

Tablo 1. Analizde Kullanılan Evlilik Kararını Etkileyebilecek Değişkenler

\begin{tabular}{|c|c|}
\hline Kategori & Değişken \\
\hline $\begin{array}{l}\text { Sosyo- } \\
\text { ekonomik } \\
\text { Değişkenler }\end{array}$ & $\begin{array}{l}\text { Çalışma durumu } \\
\text { Kişinin bitirdiği okul } \\
\text { Yerleşim yeri } \\
\text { Yaşanılan Bölge (İBBS* } 1 \text { ) }\end{array}$ \\
\hline $\begin{array}{l}\text { Evlilik Karar } \\
\text { Ölçekleri }\end{array}$ & 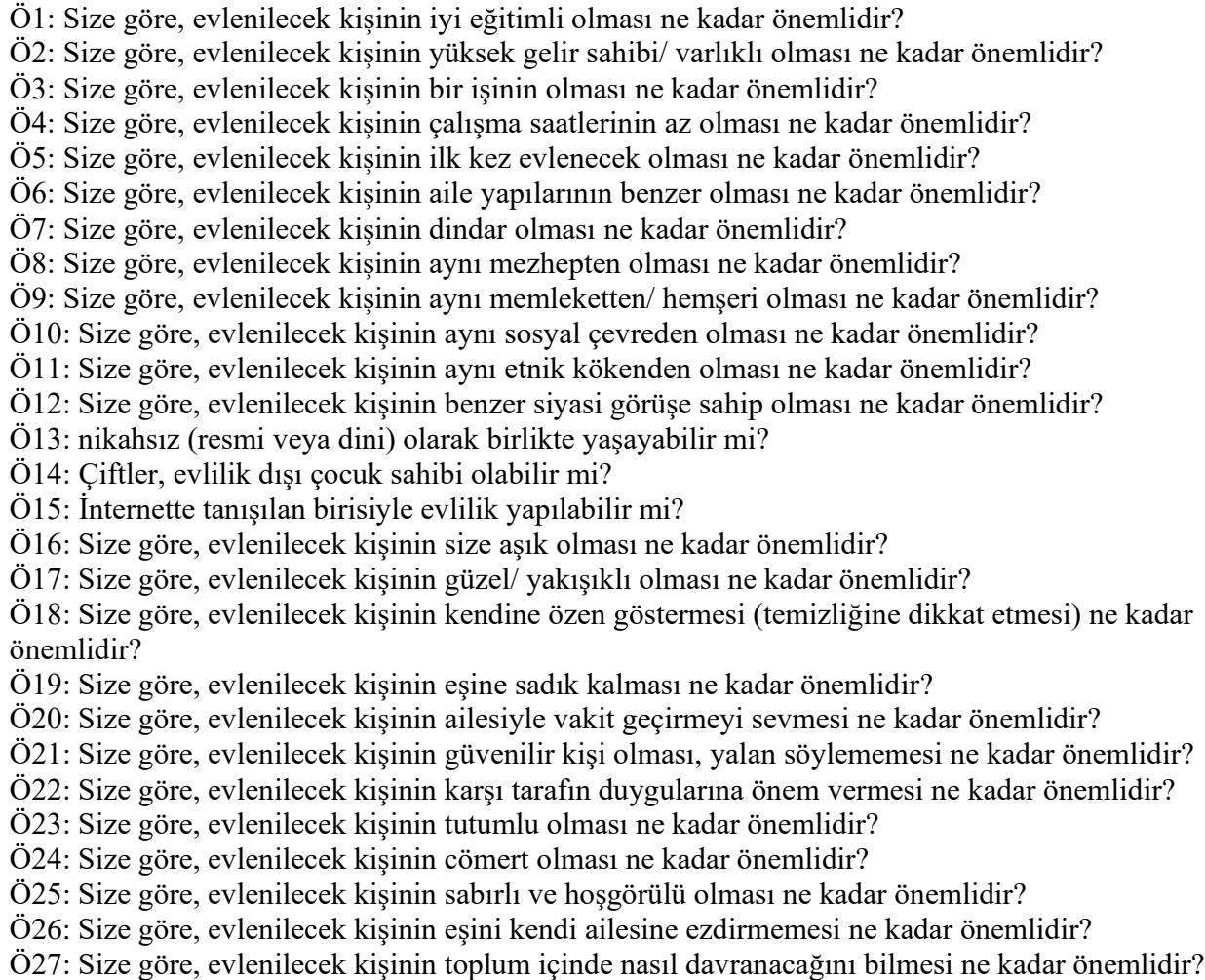 \\
\hline
\end{tabular}

\footnotetext{
* İstatistiki Bölge Birimi Sınıflaması
} 


\section{Extended Summary}

\section{The Factors Affecting the Late Marriage and Gender Differences}

Nowadays, the increase in the average age of marriage has become a problem that is frequently addressed and has many social implications. According to TurkStat data, the crude marriage rate in Turkey in 2008 is decreased $6.8 \%$ and it is also observed that the average age of marriage is 25 years for both sexes. Thus, the average age of marriage for Turkey is risen up and it is entered the process of transformation about some social problems. Studies about the average age of marriage in the literature have shown up in the 1980s, especially in western societies (Friedl \& Ellis, 1976; Booth \& Edwards, 1985). However, the majority of these studies have consisted of demographic or sociological studies also including descriptive statistics. The number of empirical studies are limited (Uchida, Araki \& Murata, 1992; Zuanna et al., 1998; Ono, 2003; Saardchom \& Lemaire, 2005). In this context, this study examines the factors affecting the age of marriage postponement or late marriage in Turkey in terms of both general and gender aspects via survival analysis.

In survival analysis, besides the time of the specific case, the effects of other factors are taken into account and the factors are included in the model. The Cox regression model is used to examine the structure between the factors considered as explanatory variables and their lifetimes (Gökmen, Eralp \& Atay Kayış, 2019). Cox model is a semi-parametric method since it does not require a specific distribution assumption. Estimation of the regression parameters of this model is determined by the Maximum Likelihood method (Cox, 1972). However, it is necessary to provide the assumption of proportional hazards for the Cox regression analysis. There are several graphical approaches and tests developed for this assumption.

In the study, the data of AYA 2016 of TUIK is considered. In the dataset, the information of a total of 22,629 people who had at most one official marriage or had never married has been used. The variable of "completed age", which is the current age, is considered as the lifetime variable. The interest here is the postponement of marriage age. However, in the literature, there is no general acceptance regarding the age of late marriage (Canatan \& Yildirim, 2018: 115). In this study, since the 2016 data is considered, the average marriage age of the same year, which is announced by TUIK, is taken as the age limit to be considered late marriage. The averages of marriage age are 25.5 for Turkey; 24 for women and 27 for men. Therefore, individuals marrying over these ages are the subject of the research. When the related studies in the literature are examined, the place and region where the individuals live, their education levels, and their working status are considered as common variables. Also, unlike the studies in the literature, the decision scales about marriage, which are included in AYA 2016 data, are examined separately, both Turkey in general and in terms of gender.

After confirming the proportional hazard assumption via Schoenfeld residuals and finding all three models significant, the estimated models have been examined in detail. In this stage, the most remarkable point is the level of education among the socio-economic variables. Accordingly, the risk of postponement of marriage for individuals who have completed primary education is about 2.5 times higher than for illiterate individuals A woman who has a postgraduate degree is approximately 6.6 times more likely to delay her marriage than a woman who has never been to school before. On the other hand, for same education levels, this rate is reached about 1.17 for men. Considering the region, it can be said that living in a city increases the risk of delaying the marriage age approximately by 0.96 times compared to living in the countryside. While this rate is estimated at about 0.56 for women and 1.63 for men.

When statistically significant marriage decision scales for Turkey are examined, to be well-educated, to have less work hours, to make his/her first marriage, to care about living 
together without marriage, to be met on the internet, to be in love, to be beautiful/handsome, to give consideration to the feelings of the partner, to be generous and to know how to act in society are seen as factors that increases the risk of delaying marriage age. It is noteworthy that the biggest factor among these factors is "love". According to this result, individuals who care about love in the marriage increase the probability of delaying their marriage decision compared to those who do not care about love for the marriage about 0.60 . The scales that reduce the risk of delaying marriage are a spouse's job, to be have a similar family structure with a spouse, they come from the same denomination/hometown/social circle, and do not offend their partners into their own families. Besides, the estimated models by gender are analyzed, the scale of "partner's having a job" is increased the delay in marriage for women, while decreasing the risk for men, according to the estimated parameter values. Another difference that is observed between men and women is that women tend to delay marriage for a generous spouse, while men reduce the risk of delaying marriage for the spouse.

As a result, the point of view of Turkish society towards the marriage institution continues to maintain its traditional structure. Conversely, factors such as love, urban life, and the participation of women in business life, similar to western societies, are the factors that statistically affected the risk of delaying marriage. The results of the study showed that there is a transformation about marriage in Turkish society. Examining the dynamics of this marriage transformation by taking into account the time dimension; it will be more effective in determining policies that can be applied in keeping the social structure dynamic. 
Optimum Journal of Economics and Management Sciences, Vo1. 7, No. 2- http://dergipark.org.trloptimum Eralp ve Gökmen - The Factors Affecting the Late Marriage and Gender Differences 